\title{
Seasonal progression of leaf rust in 'Niagara Rosada' grapevine in a biannual crop system in Brazil
}

\author{
Claudia R. Scapin-Buffara • Francislene Angelotti • \\ Nicholas S. Dufault • Carolina B. Pereira • \\ Dauri J. Tessmann
}

Accepted: 3 May 2018 / Published online: 10 May 2018

C) Koninklijke Nederlandse Planteziektenkundige Vereniging 2018

\begin{abstract}
Grapevine leaf rust, which is caused by the fungus Phakopsora euvitis, is an important late-season disease of 'Niagara Rosada' (Vitis labrusca) grapevine in Brazil. The early defoliation of plants caused by the disease impairs fruit ripening and reduces marketable yield. In a study carried out in northern Paraná State, the temporal progression of grapevine leaf rust was quantified in a production system of 'Niagara Rosada' grapevine with two growing seasons per year: mid-summerautumn and late winter-spring. The influence of weather-related variables on rust progression was examined through correlation analyses. It was observed that the rust was more severe in summer-autumn than in winter-spring. Significant positive linear correlations $(P \leq 0.05)$ were found between rust severity and rainfall $(r \geq 0.90)$ and average daily hours of leaf wetness $(r \geq$ 0.82 ). In addition, negative correlation was found between rust severity and temperature $(r \geq-0.84)$ in the mid-summer/autumn season. Mild temperatures in au-
\end{abstract}

Electronic supplementary material The online version of this article (https://doi.org/10.1007/s10658-018-1501-0) contains supplementary material, which is available to authorized users.

C. R. Scapin-Buffara • C. B. Pereira • D. J. Tessmann ( $₫)$ Departmento de Agronomia, Universidade Estadual de Maringá, Maringá, Paraná 87020-900, Brasil

e-mail: djtessmann@uem.br

F. Angelotti

Embrapa Semiárido, Petrolina, PE 56302-970, Brazil

N. S. Dufault

Department of Plant Pathology, University of Florida, Gainesville, FL 32611-0680, USA tumn were considered decisive for rust progression. In Brazilian tropical viticulture, management strategies for grapevine leaf rust must consider the risk of rust damage in autumn caused by temperature.

Keywords Phakopsora euvitis · Vitis · Epidemiology · Fungal diseases · Grape · Viticulture

\section{Introduction}

Grapevine leaf rust, also called Asian grapevine leaf rust, is caused by the fungus Phakopsora euvitis Ono. The disease was first recorded in Brazil in 2001 in northern Paraná State (Tessmann et al. 2004), and it is currently considered endemic in the southern and southeastern Brazil (Primiano et al. 2017). In 'Niagara Rosada' (Vitis labrusca L.) orchards in Paraná State, grapevine leaf rust has caused more late-season damage as a consequence of premature defoliation of plants. The disease leads to a reduction of marketable bunches due to unripe and sunburned berries (Tessmann et al. 2007).

According to the European Plant Protection Organization Global Database (EPPO 2017a), the worldwide distribution of $P$. euvitis includes Asian and American countries. It is a heteroecious rust that needs two different hosts to complete its life cycle. The uredinial and telial hosts are Vitis spp. in the Vitaceae family, and the alternate (spermogonial and aecial) host is Meliosma myriantha Sieb. \& Zucc., in the Sabiaceae family. However, this pathogen is known to only complete its life cycle in Asia because the alternate host is present there 
(Ono 2000). In Brazil, where the alternate host is absent, it is believed that the fungus overwinters by colonizing leaves of grapevine and producing urediniospores as inocula (Tessmann et al. 2004). In northern Paraná State as well in south-eastern Brazil, the table grape 'Niagara Rosada' and other grapes are produced in a biannual crop system, with the first growing season spanning from mid-summer through autumn and the second growing season from late winter through spring. The survival of leaf rust in these regions is greatly favoured by the presence of living leaves throughout the year. Even within each growing season there is some variation in pruning time, usually directed by market windows, so that the region usually is mosaic of different grape growing seasons favouring build-up of inoculum.

Under controlled conditions, the maximum infection of P. euvitis on 'Niagara Rosada' grape occurs at $20^{\circ} \mathrm{C}$, with leaf wetness duration of $12 \mathrm{~h}$, and no infection occurs above $30^{\circ} \mathrm{C}$ regardless of leaf wetness duration. The latent period at $20-25^{\circ} \mathrm{C}$ is 7 days (Angelotti et al. 2014). Yet, little is known about the field epidemiology and control of grapevine leaf rust (Leu 1988; Primiano et al. 2017). For 'Niagara Rosada' grapevine, fungicide sprays have played a key role in the management of the disease, and up to four fungicide sprays are applied each growing season. Usually, triazole fungicides are sprayed preventively after fruit set in a calendar scheme. Therefore, more information on the influence of climatic conditions on the disease progression certainly would be valuable for improving current disease management strategies related to fungicide application timing. Since its introduction in the region, it has been observed that the disease apparently occurs in a seasonal pattern. Therefore, this study aimed to quantify the temporal progression of grapevine rust in a biannual production system of 'Niagara Rosada' and to examine the influence of air temperature, leaf wetness duration, and rain accumulation on the disease progression.

\section{Materials and methods}

Experiment location and design

The experiment was carried out in an 8-year-old commercial 'Niagara Rosada' vineyard in Marialva County, northern Paraná Sate, Brazil $\left(23^{\circ} 28^{\prime} 25.92\right.$ 'S, 51 ${ }^{\circ} 49^{\prime}$ 24.31 "W, at an altitude of $566 \mathrm{~m}$ above sea level. The orchard uses a vertical trellis system with $2 \mathrm{~m}$ between rows and $1 \mathrm{~m}$ between plants within a row. The experiment was conducted as a completely randomized design with four replicates. Each replication was a $32-\mathrm{m}^{2}$ plot with 16 plants, with four vines in four consecutive rows. The treatments were the different growing seasons. Simulating a common procedure in the tropical viticulture of northern Paraná State, the grapevine was grown from late winter through spring (late August to mid-December) and from mid-summer through autumn (mid-January to late May) (Fig. 1). In addition, each growing season had two different pruning times, with an interval of 20-30 days. In 2009, winter-spring vines were pruned on August 22 and September 24; these plots were designated the late winter-spring and spring growing seasons, respectively. Subsequently, in 2010, summer-autumn vines were pruned on January 29 and February 27; these plots were designated as the midsummer-autumn and late summer-autumn growing seasons, respectively. In 2010, winter-spring vines were pruned on July 27 and August 24; these plots were designated the mid-winter-spring and late winterspring growing seasons, respectively. Lastly, in 2011, summer-autumn vines were pruned occurred on January 4 and 24; these plots were designated the early summerautumn and mid-summer-autumn growing seasons, respectively. In each pruning time, budding of the pruned branches was stimulated chemically using a $4 \%$ hydrogen cyanamide solution. The plots received no treatment with fungicide during the experiments. The use of fertilizers, weed control, and canopy management were implemented in accordance of standard production practices for the region (Kishino and Roberto 2007). A local source of inoculum (urediniospores) was present at the beginning of each cropping season in commercial plantations around the experimental plots from epidemics of grapevine rust in the previous growing season.

\section{Disease assessment}

Disease evaluations were conducted on the four central plants of each plot. The data were recorded from four randomly marked branches per plant, each containing one grape bunch for a total subsample of 16 branches per plot. Incidence and severity values were recorded from the plants by evaluating each leaf on the four branches every 18-21 days during the growing season. Incidence was calculated by counting the total number of diseased leaves divided by the total number of leaves on the four branches. Severity was directly estimated for 
Fig. 1 Diagram representing the 'Niagara Rosada' grapevine production system with two crops per year in northern Paraná State, Brazil

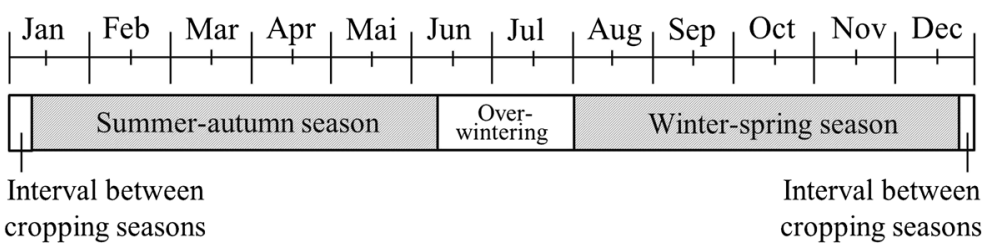

all of the leaves on each branch using disease diagrams (1.0-75.0\%) developed by Angelotti et al. (2008a). At the end of each growing season, the percentage of bunches having unripe and sunburned berries due to defoliation caused by grapevine rust (i.e., unmarketable grapes) was determined for each plot.

\section{Environmental monitoring}

Weather meteorological data consisting of hourly temperature $\left( \pm 0.6{ }^{\circ} \mathrm{C}\right)$, relative humidity $( \pm 3 \%)$, leaf wetness duration and rainfall $( \pm 2 \mathrm{~mm})$ were collected daily with a WatchDog model 450 automatic weather station data logger (Spectrum Technologies, Inc., Aurora, IL, USA) located in the experimental plot. The weather equipment operated continuously throughout the growing seasons. Sensors were placed $1 \mathrm{~m}$ above the ground.

\section{Statistical analysis}

The data of rust incidence and severity were plotted against growing degree-days (GDD) accumulation after bud bursting. GDD were calculated for the winterspring and summer-fall crop seasons based on a study of Pedro Júnior et al. (1994) for 'Niagara Rosada' grape. Epidemics were compared on the basis of maximum incidence and severity values and on the area under the disease progress curve (AUDPC) calculated from severity. To enable a comparison among the epidemics, the AUDPC was standardized by dividing the AUDPC value by the total time of the epidemics (Campbell and Madden 1990). Descriptive statistics were used to analyse the epidemic data. The influence of environmental factors on rust progression were analysed by Pearson's correlation coefficient in SAS 9.2 (SAS Institute, Cary, NC, USA) using the PROC CORR command. Correlation analysis was performed between rust severity and the following variables: accumulated rainfall, duration of leaf wetness, temperature (average, minimum and maximum) and the number of days with $6 \mathrm{~h}$ or more of leaf wetness (D6HLW). The variable D6HLW expressed the number of days favourable for rust infection and was based on a previous study by Angelotti et al. (2014). The weather variables were calculated based on averages and/or accumulated values for 18 to 21 days prior to each date of assessment of disease severity (Del Ponte et al. 2006).

\section{Results}

Grapevine leaf rust was recorded in the summer-autumn as well as in the winter-spring growing seasons, but the disease intensity, expressed by incidence and severity, was much higher in summer-autumn (Fig. 2). The maximum rust intensity ranged from 80.8 to $98.3 \%$ incidence and from 13.8 to $36.0 \%$ severity in summerautumn compared to 8.0 to $43.8 \%$ incidence and 0.2 to $3.3 \%$ severity in winter-spring. Incidence and severity were highly correlated $(r=0.91 ; P \leq 0.001)$. In 'Niagara Rosada' grapevine the flowering occurs around 3035 days after pruning and the first detection of rust in summer-autumn was before or at the flowering stage with maximum 718 ADD (Fig. 2e, g, h), except in the 2010 late summer-autumn season (Fig. 2f), when the disease was first detected at the fruit set stage. In all winter-spring growing seasons, the disease was first detected after flowering (868 to 1400 ADD). In the 2010 winter-spring season, the disease was first detected late, during the fruit ripening stage (Fig. 2c, d). The standardized AUDPC values, calculated using the percentage of severity estimates, were clearly higher in summer-autumn than in winter-spring (Fig. 3). Also, marked differences in AUDPC values were recorded among the four summer-autumn growing seasons.

Significant positive linear correlations were observed between rust severity and rainfall $(r \geq 0.90)$, average daily hours of leaf wetness $(r \geq 0.88)$, and the number of accumulated days having at least $6 \mathrm{~h}$ of leaf wetness $(r \geq 0.89)$ (Table 1). Correlations were determined for winter-spring of 2009 and for summer-autumn of 2010 and 2011 but not for winter-spring of 2010 due to a late occurrence of the disease in the last growing seasons. However, the correlations between rust severity and the 

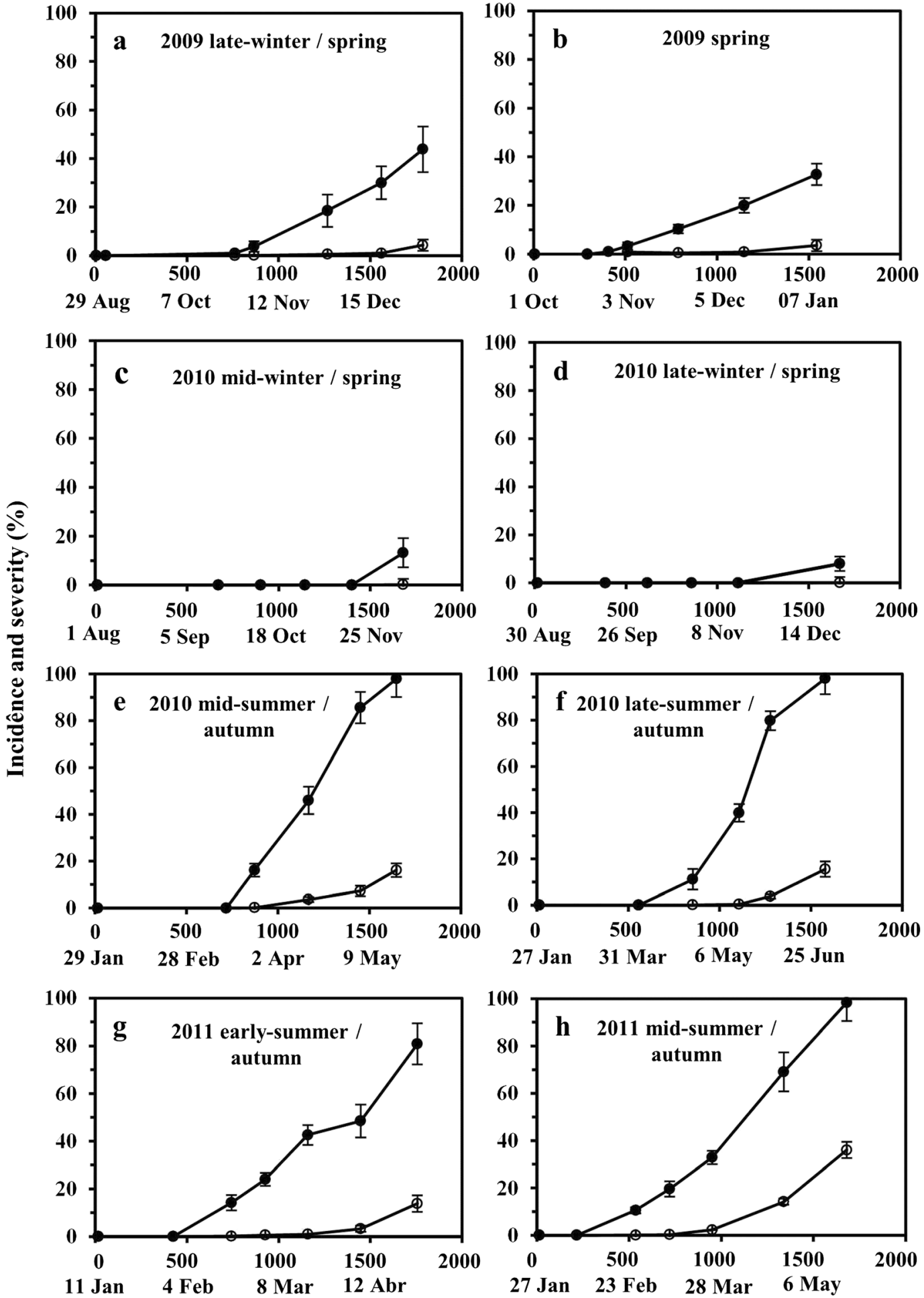

Growing degree-days

Day-of-year

Fig. 2 Incidence (black dots) and severity (white dots) progression curves of grapevine rust on 'Niagara Rosada' in different growing seasons in Paraná State, Brazil 


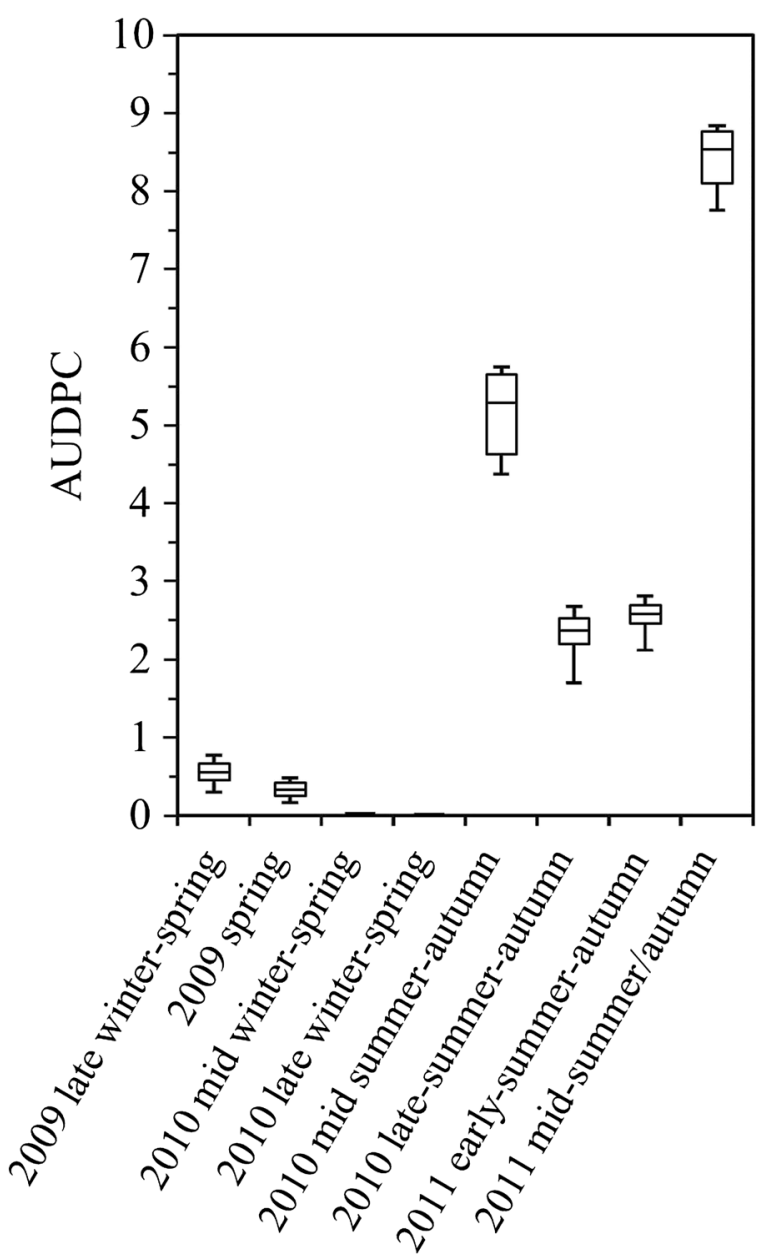

Fig. 3 Box plot for the standardized area under the disease progress curve (AUDPC) based on the severity of grapevine leaf rust in the winter-spring and summer-autumn growing seasons

average daily minimum, mean, and maximum temperatures were negative $(r \geq-0.84)$. The correlation with

Table 1 Pearson's linear correlation coefficients (The correlation coefficients were significant at $P \leq 0.05$ when shown; ns, not significant) between the severity progression of grapevine rust temperature was significant only in summer-autumn growing season.

The temperature increased throughout the winter-spring growing season, often reaching $30^{\circ} \mathrm{C}$ after the second half of the season (Fig. 4a, b), and this was different than what was observed in the summer-autumn season, when the temperature decreased from the middle to the end of the season (Fig. 4c, d). Looking more closely at the temperature during the stages of fruit set throughout berry ripening, it was observed that the average of daily mean, minimum and maximum temperatures were $24.9^{\circ} \mathrm{C}, 19.8^{\circ} \mathrm{C}$ and $30.5^{\circ} \mathrm{C}$ in the winter-spring growing seasons, and $20.1^{\circ} \mathrm{C}$, $15.7^{\circ} \mathrm{C}$ and $25.5^{\circ} \mathrm{C}$, respectively, in the summer-autumn growing seasons. The maximum severity in the winter spring growing seasons ranged from 0.2 to $3.3 \%$, and in the summer-autumn growing seasons ranged from 13.8 to $36.0 \%$ (Table 2). The rainfall distribution in the winterspring growing season was more concentrated in the spring (Fig. 4a, b), and in the summer-autumn season the rainfall was more concentrated in the summer (Fig. 4c, d).

Yield quality was reduced by the disease only in the 2011 mid-summer-autumn growing season, when $8 \%$ of bunches were considered non-marketable due to unripe and sunburned berries. This growing season had the highest values of maximum rust severity (36\%) among all the growing seasons included in this study. Due to the small amount of data, it was not possible to compute the correlation between disease severity and yield quality.

\section{Discussion}

As far as we know, this is the first study to examine the importance of environment in relation to grapevine leaf

on 'Niagara Rosada' grapevine and meteorological variables of the winter-spring and summer-autumn growing seasons in 2009, 2010, and 2011, Paraná State, Brazil

\begin{tabular}{llcr}
\hline Variables $^{\text {a }}$ & 2009 winter-spring & 2010 summer-autumn & 2011 summer-autumn \\
\hline Rainfall & 0.93 & 0.91 & 0.90 \\
$\mathrm{~T}_{\text {avg }}$ & $\mathrm{ns}$ & -0.95 & -0.84 \\
$\mathrm{~T}_{\max }$ & $\mathrm{ns}$ & -0.97 & -0.85 \\
$\mathrm{~T}_{\min }$ & $\mathrm{ns}$ & -0.90 & -0.87 \\
LW & 0.97 & 0.94 & 0.82 \\
D6HLW & 0.98 & 0.96 & 0.89
\end{tabular}

${ }^{a}$ Rainfall accumulated during the period preceding each disease assessment; $T_{\text {avg }}, T_{\max }$, and $T_{\min }$, average daily mean, maximum, and minimum temperatures, respectively; LW, daily hours with leaf wetness; D6HLW, number of accumulated days having at least $6 \mathrm{~h}$ of leaf wetness 


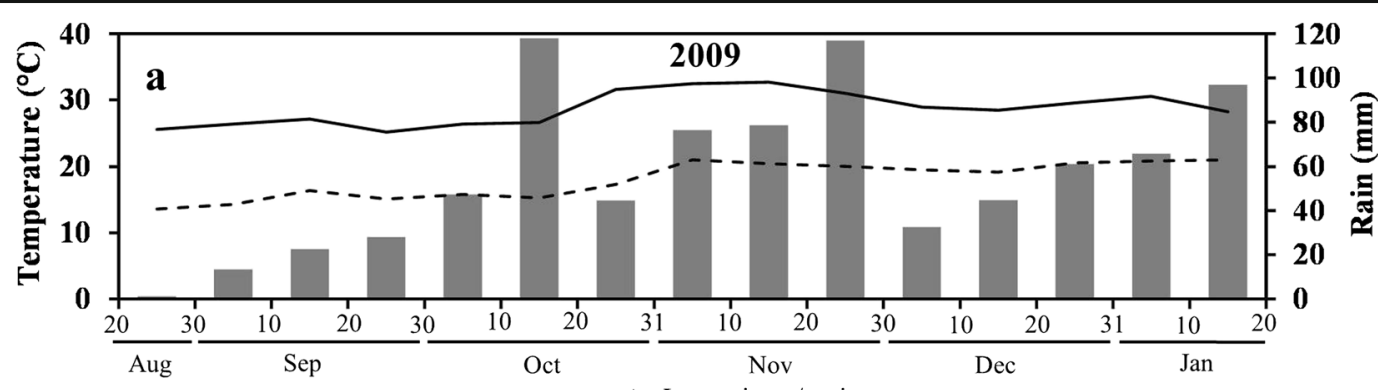

$\uparrow$ Late winter/spring
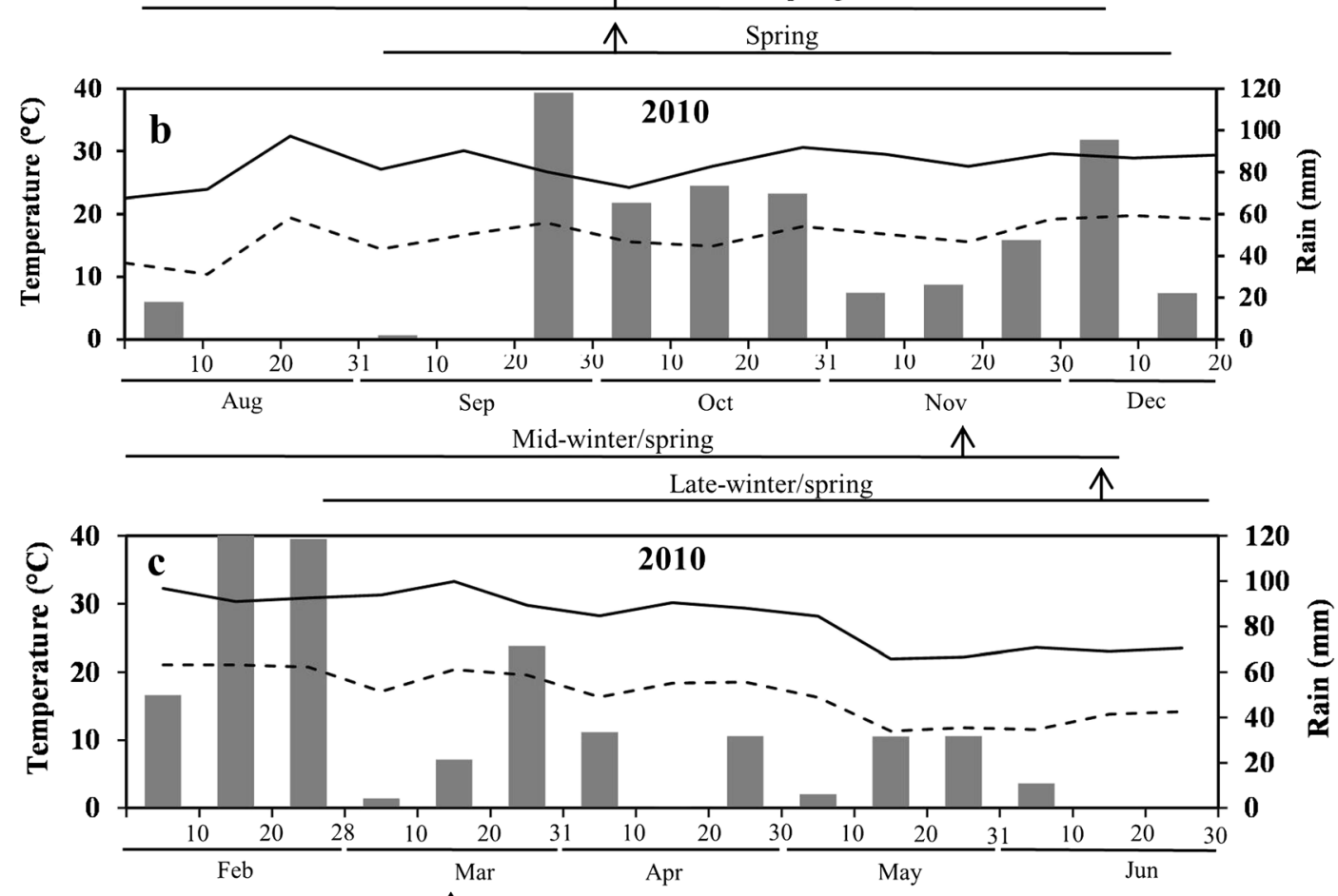

$\uparrow$ Mid-summer/autumn

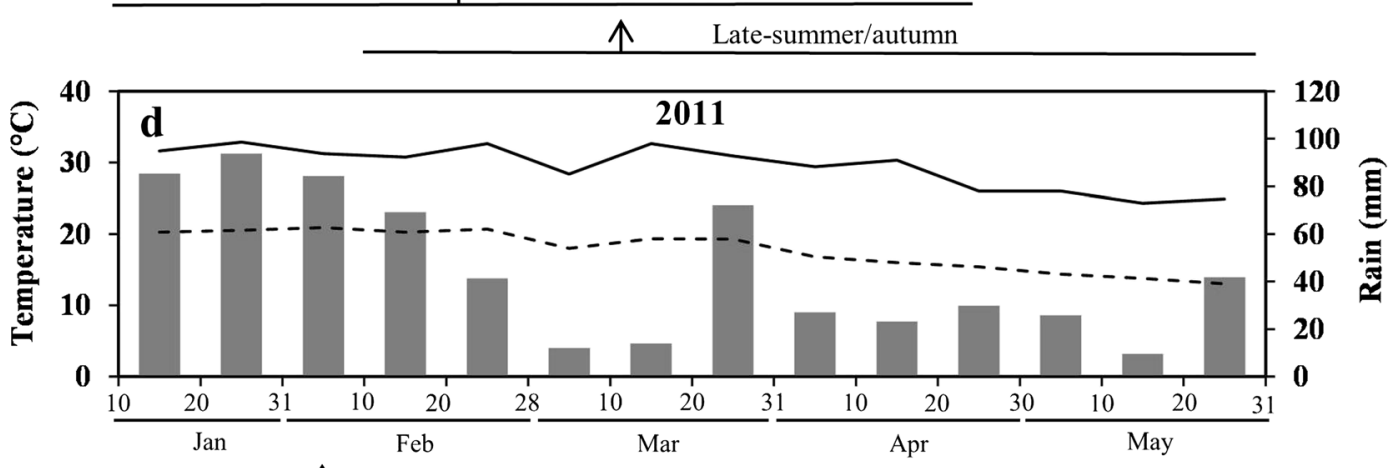

\begin{tabular}{cc}
$\uparrow$ & Early-summer/autumn \\
& Mid-summer/autumn \\
\hline
\end{tabular}

Fig. 4 Average daily maximum and minimum temperatures and daily rainfall accumulation during the grapevine growing seasons in summer-autumn and winter-spring of 2009 (a), 2010 (b and c), and 2011 (d). Arrows indicate the day when the first symptoms were recorded 
Table 2 Disease severity related to the average daily mean (Tmean), minimum (Tmin) and maximum (Tmax) temperatures during the stages of fruit set throughout berry ripening for harvest of the 2009, 2010, and 2011 growing seasons of 'Niagara Rosada' grapevine in Paraná State, Brazil

\begin{tabular}{|c|c|c|c|c|}
\hline Growing season & Maximum severity $(\%)^{\mathrm{a}}$ & Tmean $\left({ }^{\circ} \mathrm{C}\right)$ & $\operatorname{Tmin}\left({ }^{\circ} \mathrm{C}\right)$ & $\operatorname{Tmax}\left({ }^{\circ} \mathrm{C}\right)$ \\
\hline 2009 late winter-spring & $3.3 \pm 1.4$ & 25.4 & 20.1 & 31.7 \\
\hline 2009 spring & $2.6 \pm 1.2$ & 25.1 & 20.3 & 30.9 \\
\hline 2010 mid-winter-spring & $0.2 \pm 0.1$ & 24.3 & 19.1 & 29.7 \\
\hline 2010 late winter-spring & $0.2 \pm 0.1$ & 24.7 & 19.7 & 29.5 \\
\hline Average & $2.1 \pm 0.9$ & 24.9 & 19.8 & 30.5 \\
\hline 2010 mid-summer-autumn & $16.2 \pm 2.9$ & 20.9 & 15.9 & 26.1 \\
\hline 2010 late summer-autumn & $15.5 \pm 3.3$ & 18.6 & 13.4 & 25.5 \\
\hline 2011 early summer-autumn & $13.8 \pm 2.5$ & 21.1 & 17.4 & 26.2 \\
\hline 2011 mid-summer-autumn & $36.0 \pm 6.9$ & 20.0 & 16.1 & 24.3 \\
\hline Average & $19.1 \pm 3.6$ & 20.1 & 15.7 & 25.5 \\
\hline
\end{tabular}

a average \pm standard deviation

rust in the epidemics in the Paraná state of Brazil. The present study showed that grapevine leaf rust is more severe in the summer-autumn growing season than in the winter-spring one, and correlative evidence indicated that rainfall, leaf wetness duration, and temperature are important factors regarding disease development. Rainfall and leaf wetness duration correlated positively with rust progression in both growing seasons, and temperature correlated negatively with rust progression when the disease was more severe, occurring in the summer-autumn growing season. It is apparent from our results that these environmental conditions can be used to improve monitoring and management of this disease in Brazil during the different growing seasons.

Decreasing temperatures after fruit set is an important factor in determining the severity of grapevine rust epidemics. In our study, it was observed that the mild temperatures of the summer-autumn growing season during fruit set to ripening were important to grapevine rust progression. The association of grapevine rust progression with mild temperature is supported by the data from the study of Angelotti et al. (2014), who verified that the optimum temperature for grapevine infection is $20{ }^{\circ} \mathrm{C}$ and that infection does not occur at a temperature $\geq 30{ }^{\circ} \mathrm{C}$, regardless of the duration of leaf wetness.

The difference in temperatures between the two growing seasons indicates that this disease will typically be more aggressive in the summer-autumn seasons than the winter-spring. This results provides unique information about why the epidemics of grapevine rust vary from season to season.
Even though northern Paraná is a region of transition from subtropical to tropical climate, the viticulture in that region is characteristically tropical. A negative correlation between disease severity and temperature is not uncommon in tropical agriculture. A negative correlation was observed for Asian soybean rust (Phakopsora pachyrhizi Syd. \& P. Syd) in Nigeria $(r=-0.64)$ (Twizeyimana et al. 2011) and for myrtle rust (Puccinia psidii Winter) on rose apple [Syzygium jambos (L.) Alston] in Central Brazil ( $r=-0.53$ ) (Tessmann et al. 2001). Rose apple is also a perennial fruit plant that suffers from rust outbreaks in autumn. On the other hand, a study that covered a vast tropical and subtropical region of Brazil demonstrated a weak positive correlation between the severity of Asian soybean rust and temperature ( $r=0.44$ to 0.47 ) (Del Ponte et al. 2006). It will be important to evaluate the effects of temperature on grapevine rust in the other production regions of Brazil to be sure this trend is consistent.

The relevance of moisture in grapevine rust epidemics was evaluated through variables including rainfall accumulation, leaf wetness duration, and the accumulated number of days having at least $6 \mathrm{~h}$ of leaf wetness. The last variable was included with the goal of validation for future uses in the prediction of grapevine rust, but this variable differed little from the other two variables. The three variables were related to each other $(r \geq 0.94 ; P=0.0001)$. Among these variables, rainfall is especially important because it increases leaf wetness, which is essential for rust infection, and aids spore dispersal by removing spores from infected leaves 
by run-off water, splash droplets, or shaking caused by the impact of raindrops (Madden 1992). Even though temperature appears to be the main driving force of grapevine rust epidemics, moisture variables could be key to determining the severity of these epidemics. It is possible that this could be done with a simple variable such as rainfall accumulation, however, further data is needed to better understand the impacts of moisture in more severe epidemics than those examined in this study.

The 'Niagara Rosada' grapevine is among the most susceptible varieties of grapes cultivated in Brazil (Angelotti et al. 2008b). The loss of $8 \%$ in marketable bunches was much lower than the $100 \%$ loss reported in a previous study in 2004 (Vida and Tessmann 2005). Grapevine leaf rust is a potentially harmful disease, and there is good reason for its quarantine in many countries (EPPO 2017b). The information from this study suggests that the disease is seasonal and that its progression is strongly influenced by weather. In this situation, fungicide sprays certainly are proper disease control measures for the disease, but their optimization requires further study.

The epidemiological information for grapevine leaf rust obtained in this study is especially valid for tropical viticulture. The results showed that climatic conditions prior to outbreaks of grapevine rust are clearly correlated with disease severity; thus, the probability of a severe epidemic can be anticipated each year. In this study, the initial inoculum was present in all of the growing seasons, but further studies could quantify the urediniospores present in the environment prior and during the outbreaks. This quantification could provide a better understanding of the inoculum build-up process in grapevine leaf rust epidemics. It appears that temperature is the main factor behind grapevine rust epidemics, which is important for producers when consider fungicide application timing. However, more information about moisture and the possible variation that exists in the pathogen throughout the region could help refine tropical viticulture management strategies in the future.

Acknowledgements This research was supported by funds from the National Council for Scientific and Technological Development (CNPq; grant 550.552/2009-0), and CAPES Foundation of the Ministry of Education of Brazil (grant BEX 8576/11-4) for sandwich program at University of Florida.
Funding This study was funded by the National Council for Scientific and Technological Development of Brazil (CNPq; grant $550.552 / 2009-0)$ and CAPES Foundation of the Ministry of Education of Brazil (scholarship grant BEX 8576/11-4).

\section{Compliance with ethical standards}

Conflict of interest Claudia R. Scapin-Buffara declares that she has no conflict of interest; Francislene Angelotti declares she has no conflict of interest; Nicholas S. Dufault declares he has no conflict of interest; Carolina B. Pereira declares she has no conflict of interest; and Dauri J. Tessmann declares he has no conflict of interest.

Ethical approval This article does not contain any studies with human participants or animals performed by any of the authors.

\section{References}

Angelotti, F., Scapin, C. R., Tessmann, D. J., Vida, J. B., \& Canteri, M. G. (2008a). Diagrammatic scale for assessment of grape rust. Tropical Plant Pathology, 33, 439-443.

Angelotti, F., Scapin, C. R., Tessmann, D. J., Vida, J. B., Vieira, R. A., \& De Souto, E. R. (2008b). Resistência de genótipos de videira à ferrugem. Pesquisa Agropecuária Brasileira, 43, 11291134.

Angelotti, F., Scapin, C. R., Tessmann, D. J., Vida, J. B., \& Canteri, M. G. (2014). The effect of temperature, leaf wetness and light on development of grapevine rust. Australasian Plant Pathology, 43, 9-13.

Campbell, C. L., \& Madden, L. V. (1990). Introduction to plant disease epidemiology. New York: Wiley-Interscience.

Del Ponte, E. M., Godoy, C. V., Li, X., \& Yang, X. B. (2006). Predicting severity of Asian soybean rust epidemics with empirical rainfall models. Phytopathology, 96, 797-803.

EPPO (2017a) EPPO global database. https://gd.eppo. int/taxon/PHLLAM/distribution. Accessed 20 March 2017.

EPPO (2017b) EPPO global database. https://gd.eppo. int/taxon/PHLLAM/categorization. Accessed 22 March 2017.

Kishino, A. Y., \& Roberto, S. R. (2007). Tratos culturais. In A. Y. Kishino, S. L. Carvalho, \& S. R. Roberto (Eds.), Viticultura Tropical: o sistema de produção do Paraná (pp. 171-202). IAPAR: Londrina.

Leu, L. S. (1988). Rust. In R. C. Pearson \& A. C. Goheen (Eds.), Compendium of Grape Diseases (pp. 28-30). St. Paul: The American Phytopathological Society.

Madden, L. V. (1992). Rainfall and dispersal of fungal spores. Advances in Plant Pathology, 8, 39-79.

Ono, Y. (2000). Taxonomy of the Phakopsora ampelopsidis species complex on vitaceous hosts in Asia including a new species, P. euvitis. Mycologia, 92, 154-173.

Pedro Júnior, M. J., Sentelhas, P. C., Pommer, C. V., \& Martins, F. P. (1994). Determinação da temperature-base, graus dia e índice biometeorológico para a videira 'Niagara Rosada'. Revista Brasileira de Agrometeorologia, 2, 51-56. 
Primiano, I. V., Loehrer, M., Amorim, L., \& Schaffrath, U. (2017). Asian grapevine leaf rust caused by Phakopsora euvitis: An important disease in Brazil. Plant Pathology, 66, 691-672.

Tessmann, D. J., Dianese, J. C., Miranda, A. C., \& Castro, L. H. R. (2001). Epidemiology of a Neotropical rust (Puccinia psidii): Periodical analysis of the temporal progress in a perennial host (Syzygium jambos). Plant Pathology, 50, 725-731.

Tessmann, D. J., Dianese, J. C., Genta, W., Vida, J. B., \& Mio, L. L. M. (2004). Grape rust caused by Phakopsora euvitis, a new disease for Brazil. Fitopatologia Brasileira, 29, 338.
Tessmann, D. J., Vida, J. B., Genta, W., \& Kishino, A. Y. (2007). Doenças e seu manejo. In A. Y. Kishino, S. L. C. Carvalho, \& S. R. Roberto (Eds.), Viticultura Tropical: o sistema de produção do Paraná (pp. 255-304). Londrina: IAPAR.

Twizeyimana, M., Ojiambo, P. S., Hartman, G. L., \& Bandyopadhyay, R. (2011). Dynamics of soybean rust epidemics in sequential plantings of soybean cultivars in Nigeria. Plant Disease, 95, 43-50.

Vida, J. B., \& Tessmann, D. J. (2005). Losses caused by the rust Phakopsora euvitis on grapevines. Fitopatologia Brasileira, 30, S140 (abstract). 